\title{
UPAYA MENINGKATKAN ETOS KERJA GURU MELALUI BUDAYA DISIPLIN WAKTU
}

\author{
Wahyu Werdiningsih' \\ Dr. H.A.Supriyanto, M.Pd, M.Si ${ }^{2}$ \\ Dr. H. Agus Timan, M.Pd ${ }^{3}$ \\ Universitas Negeri Malang, Jl. Semarang 5 Malang 65I45 \\ Email: werdiningsih.wahyu@yahoo.co.id
}

\begin{abstract}
The purpose of this study was to determine the teacher's work ethic and time discipline culture. This research uses descriptive design. The study population included all teachers at SDIT Robbani Malang. The research data was collected through interviews, observations, and relevant documentation. Then the data was analyzed using descriptive techniques. The findings in the field indicate that: (I) work ethics measured by teacher discipline need to be improved, (2) periodic control and evaluation need to be improved, (3) reviewing staffing rules with clear and consistent reward and punishment, and (4) need for motivation and coaching in changing the mental attitude of the teacher.
\end{abstract}

Keywords : Work Ethic, Culture, Dicipline

Abstrak: Tujuan penelitian ini untuk mengetahui etos kerja guru dan budaya disiplin waktu. Penelitian ini menggunakan desain deskriptif. Populasi penelitian termasuk semua guru di SDIT Robbani Malang. Data penelitian ini dikumpulkan melalui wawancara, observasi, dan dokumentasi yang relevan. Selanjutya data tersebut dianalisis dengan menggunakan teknik deskriptif. Temuantemuan di lapangan menunjukkan bahwa: (I) etika kerja yang diukur oleh disiplin guru perlu ditingkatkan, (2) kontrol dan evaluasi berkala perlu ditingkatkan, (3) meninjau aturan kepegawaian dengan imbalan dan hukuman yang jelas dan konsisten, dan (4) perlunya motivasi dan pembinaan dalam mengubah sikap mental guru.

Kata Kunci : Etos Kerja, Budaya, Disiplin

\section{Pendahuluan}

Peran guru dalam proses pembelajaran sangat penting untuk mencapai tujuan pendidikan, karena guru berinteraksi secara langsung dengan peserta didik. Guru dituntut dapat menjalankan perannya secara optimal. Sebagai pendidik, guru memiliki tugas utama untuk mendidik, mengajar, membimbing, mengarahkan, melatih, menilai, dan mengevaluasi peserta didik . Terdapat seperangkat kompetensi yang harus dimiliki oleh guru di dalam menjalankan tugas dan perannya. Undang-Undang Nomor 14 Tahun 2005 tentang Guru dan Dosen, pasal 10 ayat (I) menyatakan kompetensi guru terdiri dari kompetensi pedagogik, kepribadian, sosial, dan professional. Keempat kompetensi tersebut diperoleh melalui pendidikan profesi. Menurut undang-undang tersebut di atas, secara khusus kompetensi kepribadian adalah kemampuan personal yang mencerminkan kepribadian yang mantap, stabil, dewasa, arif dan berwibawa, dapat menjadi teladan bagi peserta didik, dan berakhlak mulia. Bagian dari kompetensi kepribadian yang harus dimiliki guru adalah kepribadian yang dewasa yaitu menampilkan kemandirian dalam bertindak sebagai pendidik dan memiliki etos kerja sebagai guru. Di samping itu guru hendaknya memiliki kepribadian yang berwibawa, artinya guru memiliki sikap perilaku yang memberi pengaruh positif atau keteladanan dan disegani oleh peserta didik. 
Menurut K. Bertens (1994), istilah etos secara etimologis berasal dari bahasa Yunani yang memiliki arti tempat hidup. Pada awalnya tempat hidup dimaknai sebagai suatu adat istiadat atau kebiasaan. Menurut Anoraga (2009), etos kerja adalah suatu pandangan dan sikap suatu bangsa atau umat terhadap kerja. Sedangkan menurut Sinamo (2005), etos kerja adalah seperangkat perilaku positif yang berakar pada keyakinan fundamental, disertai dengan komitmen total pada paradigma kerja yang integral atau menyeluruh. Menurutnya, jika seseorang, suatu organisasi, atau suatu komunitas menganut cara pandang atau paradigma kerja, kemudian memiliki kepercayaan dan komitmen pada paradigma kerja tersebut, maka akan melahirkan sikap dan perilaku kerja yang khas yang akayang disebut budaya kerja. Dengan demikian etos kerja menjadi pondasi kesuksesan sejati bagi seseorang atau suatu komunitas.

Istilah etos digunakan oleh Sinamo karena menemukan bahwa kata etos mengandung pengertian sebagai perilaku khas dari sebuah organisasi atau komunitas dan mencakup pula motivasi, karakteristik utama, spirit dasar, pikiran dasar, kode etik, kode moral, kode perilaku, sikap-sikap, aspirasi-aspirasi, keyakinan-keyakinan, prinsip-prinsip, dan standar-standar.

Dari berbagai pengertian di atas dapat disimpulkan bahwa etos kerja merupakan seperangkat sikap atau cara pandang yang mendasar dari sekelompok manusia untuk menilai bahwa bekerja merupakan suatu hal yang positif untuk meningkatkan kualitas hidup dan mempengaruhi perilakunya dalam bekerja.

Berikut adalah beberapa faktor yang mempengaruhi etos kerja, yaitu faktor agama, sosial budaya, politik, kondisi lingkungan atau geografis, kualitas sumber daya manusia, dan motivasi internal individu. Anoraga (2009) mengatakan bahwa individu yang memiliki etos kerja tinggi adalah individu yang memiliki motivasi tinggi. Etos kerja didasari oleh nilai-nilai yang diyakini seseorang. Keyakinan ini akan menumbuhkan suatu motivasi kerja yang akan mempengaruhi etos kerjanya. Dari uraian di atas tampak bahwa diantara faktor penting yang mempengaruhi etos kerja adalah budaya, meliputi sikap mental, tekad, disiplin dan semangat kerja. Secara khusus dalam artikel ini akan dibahas tentang kedisiplinan guru sebagai salah satu faktor yang mementukan etos kerjanya.

Menurut Siagian (2009) disiplin adalah suatu tindakan manajemen untuk mendorong para anggota organisasi dalam memenuhi tuntutan sesuai ketentuan atau standar tertentu. Kedisiplinan juga diartikan sebagai peraturan yang dilakukan dengan ketegasan jiwa dan penuh tanggung jawab. Kedisiplinan merupakan salah satu fungsi dari manajemen sumber daya manusia yang terpenting. Semakin tinggi tingkat kedisiplinan seseorang, maka akan semakin tinggi pula prestasi kerja yang dapat dicapainya. Dengan kedisiplinan dapat menumbuhkan perasaan seseorang untuk mempertahankan dan meningkatkan tujuan organisasi yang dicapai melalui kepatuhannya dalam menjalankan peraturan-peraturan organisasi.

\section{METODE}

Penelitian ini bertujuan untuk menganalisis tingkat kedisiplinan guru di lingkungan SDIT Robbani Singosari Malang. Penelitian ini menggunakan rancangan penelitian eksperimental dengan mengungkapkan data dan fakta yang ada di lapangan, selanjutnya dilakukan tindakan sebagai upaya solusi permasalahan yang ada. Variabel, sub variabel, dan indikator penelitian ini sebagaimana tampak dalam Tabel I. 
Tabel I.

Variabel, Sub Variabel dan Indikator Penelitian

\begin{tabular}{|l|l|l|}
\hline Variabel & Sub Variabel & Indikator \\
\hline Etos kerja & Motivasi internal guru & $\begin{array}{l}\text { Tingkat kehadiran guru dan } \\
\text { Tingkat keterlambatan guru } \\
\text { Evaluasi dan kontrol KS } \\
\text { Evaluasi dan kontrol Yayasan }\end{array}$ \\
\hline Budaya disiplin waktu & Kebijakan Sekolah & $\begin{array}{l}\text { Aturan Kepegawaian } \\
\text { Raport Guru } \\
\text { Reward dan punishment }\end{array}$ \\
& Sarana dan prasarana & Penggunaan finger print \\
\hline
\end{tabular}

Populasi penelitian ini sebanyak 32 orang, meliputi satu orang kepala sekolah dan 3 I guru. Pengumpulan data dalam penelitian ini menggunakan teknik wawancara, observasi, dan dokumentasi. Observasi lapangan dilakukan untuk melihat secara riil kehadiran dan keterlambatan guru SDIT Robbani. Wawancara dilakukan terhadap staf administrasi dan beberapa guru, serta dokumentasi yang relevan dengan penelitian. Teknik analisis deskriptif kualitatif digunakan untuk memberikan gambaran kondisi nyata yang ada di lapangan. Langkah-langkah analisis meliputi pengumpulan data, reduksi data, pengolahan data dan penarikan kesimpulan.

\section{HASIL DAN PEMBAHASAN}

Hasil penelitian dapat dijabarkan sebagaimana variabel yang diteliti yaitu etos kerja dan budaya disiplin waktu. Etos kerja guru dan karyawan di SDIT Robbani adalah cukup baik ditinjau dari motivasi kerja dengan menganalisa tingkat kehadiran dan keterlambatan guru. Dari data empat bulan terakhir pada rentang waktu bulan November tahun 2018 sampai dengan bulan Februari tahun 2019, tingkat kehadiran guru mencapai angka rata-rata $93 \%$ per bulan., sedangkan tingkat keterlambatan guru relatif tinggi yaitu mencapai rata-rata $12 \%$ per bulan. Sebab atau alasan ketidakhadiran guru secara umum karena sakit, keperluan keluarga atau dinas luar seperti pelatihan di luar kota. Adapun sebab atau alasan keterlambatan juga beragam diantaranya karena jarak rumah dan sekolah relatif jauh, jalanan macet, menyelesaikan urusan rumah tangga, dan mengantar anak sekolah di tempat yang berbeda. Tingkat kehadiran yang diharapkan adalah $100 \%$ per bulan, sedangkan keterlambatan maksimal rata-rata $5 \%$ per bulan.

Analisa masalah ketidakhadiran dan keterlambatan guru di SDIT Robbani dengan menggunakan diagram pohon seperti pada Gambar.I 


\section{Analisa Masalah dengan Diagram Pohon Gambar.I}

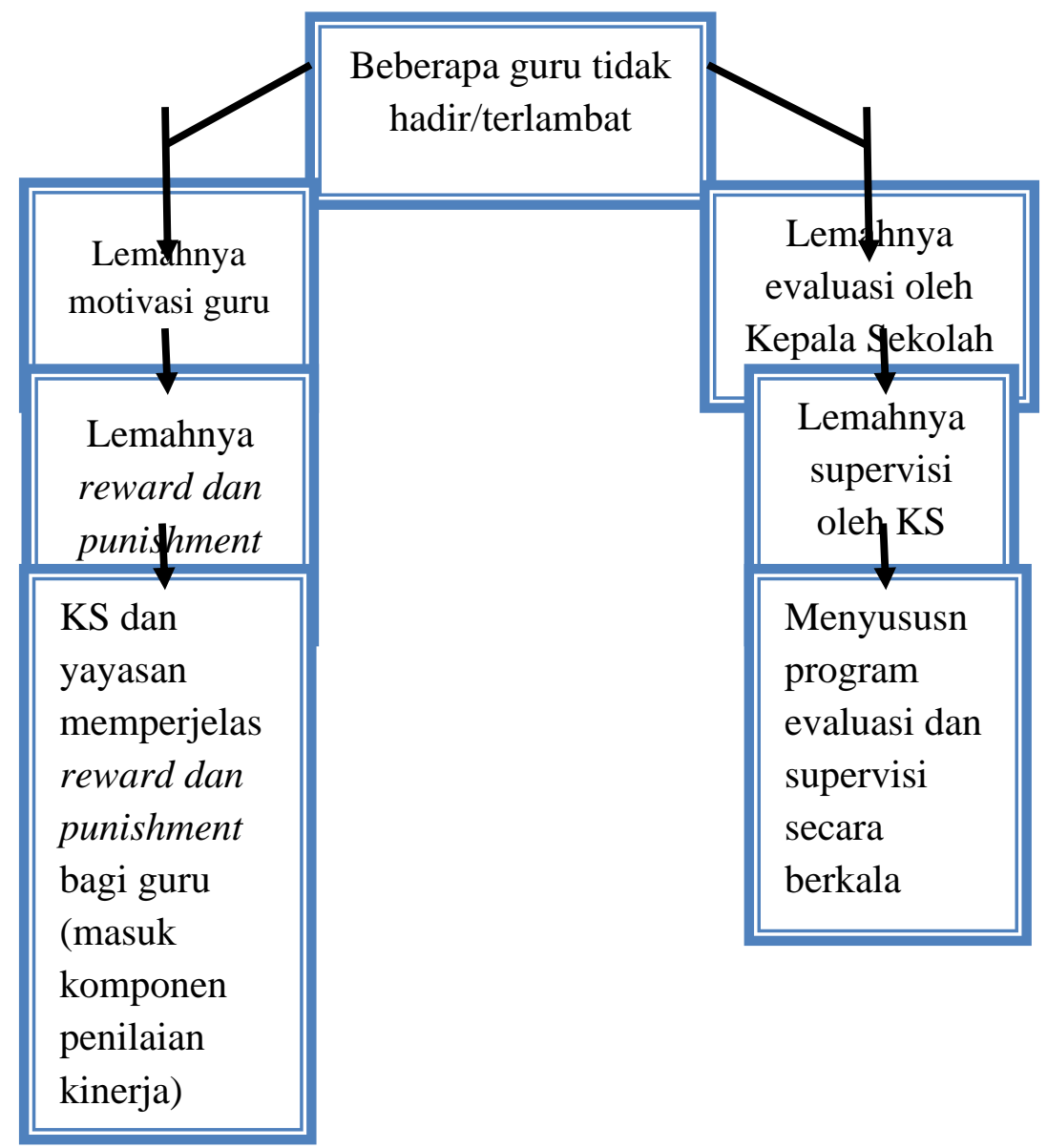

Dari analisa masalah di atas, melalui peran kepala sekolah dan yayasan dilakukan kontrol dan evaluasi secara berkala setiap bulan. Aturan kepegawaian dari yayasan yang diterapkan sudah mengatur tentang jam kerja harian guru, perizinan, cuti, perjalanan dinas luar. Dilengkapi dengan tata tertib guru yang berlaku di sekolah. Untuk efektifitas dan efisiensi dalam melakukan control dan evaluasi sekolah sudah menggunakan alat berupa finger print, sehingga dapat memberikan data yang lengkap dan valid. Tingkat kehadiran dan keterlambatan guru juga menjadi acuan penilaian kinerja guru oleh kepala sekolah dan yayasan, dan berdampak pada pemberian reward dan punishment.

\section{Pembahasan}

Di SDIT Robbani Malang sudah dilaksanakan upaya peningkatan etos kerja guru melalui budaya disiplin waktu, meskipun hasilnya belum optimal. Tingkat kehadiran guru perlu ditingkatkan sehingga tidak mengganggu proses belajar mengajar. Sementara tingkat keterlambatan guru juga harus diminimalisir, agar guru dapat memberikan keteladanan kepada peserta didik. Kontrol dan evaluasi dari kepala sekolah dan yayasan sudah berjalan, namun demikian diharapkan lebih intensif. Penggunaan finger print dan pengelolaannya oleh bagian administrasi sekolah hendaknya dapat dioptimalkan dan dikontrol dengan lebih baik. Reward dan punishment bagi guru yang tidak hadir atau terlambat sudah ada tetapi belum berjalan secara konsisten. Misal pemberian reward atau apresiasi bagi guru yang paling rajin atau tingkat kehadiranya paling tinggi pada rentang waktu tertentu. Untuk punishment sementara diberlakukan pemotongan gaji sesuai dengan hari atau jam 
yang ditinggalkan. Belum ada tindakan lainnya yang mampu menigkatkan etos kerja guru, misalnya berupa surat peringatan atau pemanggilan guru untuk dilakukan pembinaan bilamana guru melampaui toleransi ketidakhadiran atau keterlambatan.

Yayasan perlu membuat aturan yang lebih jelas dan tegas sehingga mampu merubah sikap mental guru dalam hal kedisiplinan. Kedisiplinan guru dapat ditingkatkan dengan memperhatikan prinsip-prinsip berikut: (I) pemimpin harus menjadi teladan bagi anak buah , (2) tindakan indisipliner diberlakukan berdasarkan data yang akurat, (3) pemimpin memiliki kepekaan terhadap pelanggararan anak buah, dan mengatasinya dengan bijaksana, (4) menjaga privasi anak buah dan penyelesaian masalah secara personal, (5) fokus pada permasalahan anak buah, bukan pada pribadinya, (6) peraturan ditegakkan secara konsisten, (7) fleksibel dan tidak kaku, dan (8) evaluasi yang berkesinambungan atau terus menerus.

\section{KESIMPULAN}

Guru memegang peranan penting dalam proses pembelajaran peserta didik, oleh karenanya etos kerja guru menjadi salah satu faktor utama dalam mengoptimalkan tugas dan perannya. Budaya disiplin waktu menjadi salah satu fokus masalah yang terus diupayakan penyelesaiannya di SDIT Robbani Malang dengan melakukan perbaikan secara terus-menerus dalam upaya meningkatkan mutu pendidikan. Tingkat kehadiran guru perlu dioptimalkan lagi, dan tingkat keterlambatan guru harus diminimalisir. Semua pihak baik kepala sekolah, yayasan dan guru harus terlibat secara langsung dalam proses peningkatan etos kerja, dan memiliki komitmen serta motivasi yang tinggi untuk dapat mencapainya.

\section{Saran}

Kepala sekolah dan yayasan melaksanakan kontrol dan evaluasi terhadap kedisiplinan secara berkala. Aturan kepegawaian dilengkapi dengan reward dan punishment yang lebih jelas, berdampak positif dan dijalankan secara konsisten. Sebagai kegiatan pendukung perlu adanya penguatan motivasi kepada guru secara khusus dan pembinaan berkelanjutan guna meningkatkan etos kerja.

\section{DAFTAR PUSTAKA}

Bertens, K. 1994. Etika.Gramedia, Jakarta

Sinamo, Jansen. 2005. Delapan Etos Kerja Profesional: Navigator Anda Menuju Sukses. Grafika Mardi Yuana, Bogor.

Anoraga, Pandji. 2009. Manajemen Bisnis. Rineka Cipta, Jakarta.

Siagian, Prof. Dr. Sondang P.1995. Teori Motivasi Dan Aplikasinya. Rineka Cipta, Jakarta. Undang-undang Nomor 14 Tahun 2005 Tentang Guru dan Dosen 